\title{
Article
}

\section{Asset or Liability: Transnational Links and Political Participation of Foreign-Born Citizens in Taiwan}

Cheng, Isabelle, Momesso, Lara and Fell, Dafydd

Available at http://clok.uclan.ac.uk/24595/

Cheng, Isabelle, Momesso, Lara ORCID: 0000-0002-4042-9384 and Fell, Dafydd (2019) Asset or Liability: Transnational Links and Political Participation of Foreign-Born Citizens in Taiwan. International Migration, 57 (4). pp. 202217. ISSN 0020-7985

It is advisable to refer to the publisher's version if you intend to cite from the work. http://dx.doi.org/10.1111/imig.12534

For more information about UCLan's research in this area go to http://www.uclan.ac.uk/researchgroups/ and search for <name of research Group>.

For information about Research generally at UCLan please go to http://www.uclan.ac.uk/research/

All outputs in CLoK are protected by Intellectual Property Rights law, including Copyright law. Copyright, IPR and Moral Rights for the works on this site are retained by the individual authors and/or other copyright owners. Terms and conditions for use of this material are defined in the policies page.

\section{CLoK}

Central Lancashire online Knowledge www.clok.uclan.ac.uk

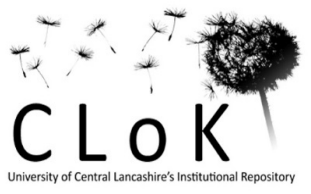




\title{
Asset or Liability: Transnational Links and Political Participation of Foreign- Born Citizens in Taiwan
}

\begin{abstract}
Viewed as outsiders clinging onto links with their country of origin, immigrants do not often feature positively in electoral politics in their host society. Challenging this conventional view, this paper examines how immigrants make use of their transnational ties to foster their political participation in the host state. This exploration is conducted through our study of the political participation of Vietnamese and Chinese immigrants in Taiwan. Our research finds that transnational ties are politicised by the mainstream political parties. However, such politicisation does not necessarily restrict immigrants' agency and their socio-political space for political participation. Their transnational ties constitute a dynamic socio-political field in which these maintained connections are acted upon and give rise to a variety of strategies for responding to issues affecting their interests.
\end{abstract}

Keywords: political participation, politics of in-between, transnationalism, marriage migration, New Southbound Policy, the Rejuvenation of Chinese Nation.

\section{INTRODUCTION}

Immigrants around the world have started to participate more actively in the politics of hosting societies. In Belgium, there was an increase in the number of politicians of Moroccan origin elected in the Brussels-Capital Region in 2000 (Jacobs et al. 2002). In the Netherlands, there are councillors representing the four largest ethnic minorities in four big cities (Fennema and Tillie 2001). In the US, there is a noticeable growth of public campaigns and civic organisations launched by Latino immigrants who perceive that their interests are under threat by mainstream partisan politics (Barreto 2005; Barreto et al. 2009). Most recently, attention to migration issues surged globally in the wake of Brexit and the unfolding of Donald Trump's presidency. The world is watching closely how Brexit and the Trump Administration's manoeuvring to make the US a "walled state" (Brown 2010) will affect global migration.

However, immigrants do not participate in the public forum in a socio-political vacuum. Transnationalism argues that migrants and the hometown organisations founded by them are surrounded by strongly retained political and socio-economic links with both the origin and receiving states (Glick Schiller et al. 1995; Portes et al. 1999; Grillo and Salih 2000; Castles 2000; Castles and Miller 2009). What requires a deeper understanding is how these maintained connections affect their political participation at both ends. Engaging with this debate and considering the equally significant role played by the origin and receiving states, this paper raises the following questions: How do political parties of the receiving state incorporate immigrants' transnational ties into their campaign strategies? How do immigrants react to political parties' electioneering in their political participation? Using the political participation of migrant wives in Taiwan as a case study, the findings of this paper will enrich the concept of the "politics of in-between" coined by Jones-Correa (1998a) and demonstrate how Taiwan's electoral politics and the unsettled 
relationship with China may constitute a socio-political arena for foreign-born citizens to exercise their political rights.

\section{IMMIGRANTS' POLITICAL PARTICIPATION}

Political participation in electoral politics is mostly understood as people's attempt to affect public policy-making or influence the selection of policy makers. They can do so by going to vote, running for election, protesting, demonstrating or boycotting. Whether and how they participate are affected by their education, vocation, incomes, personal beliefs, political orientation, as well as by influence from family members (Gidengil et al. 2010; Schaffer 2014) and their exposure to social networks outside of family (Liu and Chiu 2011). When the voter is an immigrant, the significance of language proficiency and knowledge about mainstream politics of the receiving state (Hammar 1990: 150-168), as well as ethnicity, comes to the fore. Immigrants of different origins may participate at different rates in terms of voting and standing for public offices (Leighley and Vedlitz 1999; Cho 1999; Fennema and Tillie 2001). The circumstances under which immigrants enter the host state, such as their eligibility for citizenship and the conditions for exercising citizenship (Martiniello 2005), can hinder or shape their political incorporation (Pantoja et al. 2001; Barreto and Muñoz 2003).

In the wake of the feminisation of migration, whereby women outnumber men (as in the case of Taiwan as a destination for women who migrate because of their transnational marriages), gender is an indispensable variable. Elshtain (1974) argues that political participation takes place in a domain considered male in consequence of the Aristotelian paradigm of power politics, which separates the political, rational, amoral space of the polis from the private, intimate, emotional realm of the home. As a result, men are conceptualised as "public" subjects, whereas women are considered private (Elshtain 1974). However, this public-private division is challenged by the recognition of women's involvement in community affairs at grassroots level as their political participation (Jones-Correa 1998b; Thiara 2003; Roces 2003; Ho 2008; Briones 2009; Cheng 2017). Not only do they demonstrate their agency, they also acquire civic skills and social capital necessary for political participation (Putnam 2002; Harell 2009).

However, immigrants' political participation does not grow in isolation from their transnational links. Immigrants engage in individual or collective activism so as to improve their legal status in the receiving state, or participate in the development projects or homeland politics of the origin state (Martiniello and Lafleur 2008). The concept of a "politics of in-between" (Jones-Correa 1998a) analyses immigrants' dynamic understanding of how they negotiate their political experiences obtained before and after migration. Paying attention to the political environment at both ends of migration, Jones-Correa finds that Latino immigrants' political participation in New York is a response to partisan politics in the receiving state, the conceptualisation of naturalisation, and their political socialisation prior to migration (1998a: 4-5, 127129). Sandwiched in between, both naturalised Latino citizens and non-citizens keep their distance from, at the same time as maintaining ties with, both ends of their migration. By doing so, they construct a "fluid politics of identity" that allows them to retain cultural ties with the country of origin and reduce institutional constraints that 
they perceive are acting on them (Jones-Correa 1998a: 6).

\section{RESEARCH DESIGN AND METHODS}

Inspired by the concept of the "politics of in-between" and aligned with the call for studying "transnationalism from below" (Smith and Guarnizo 1998), this research seeks to understand the impact of transnationalism on immigrants' political participation at both ends. That is, we explore the "politics of in-between" in terms of how immigrants interact with the mainstream political parties in the receiving state through their transnational ties. Our case study is the political participation of Vietnamese and Chinese migrant wives in Taiwan in regard to their interactions with the election campaign strategies of the two major political parties. One of these parties is the Democratic Progressive Party (DPP), which promotes the Taiwanese identity and adopted a more confrontational stance towards the People's Republic of China (PRC) in its first presidency during 2000-2008 (Hsu 2012). The other is the Kuomintang (KMT), which stands for a stronger Chinese identity, and, when taking over from the DPP between 2008 and 2016, developed a more cooperative relationship with the PRC (Beckershoff 2014).

This research design is based upon the characteristics of Taiwan's domestic politics and external relations. First of all, the comparison between Vietnamese and Chinese immigrants, the two largest immigrant groups, is drawn from their contrasting attributes, assessed by some of the variables explained above. As women citizens, they differ from each other in terms of ethnicity and Chinese language proficiency, which influences the extent of their understanding of public affairs, social networking, civic skills and social capital. Their Taiwanese husbands and in-laws play a certain role in the development of their political inclinations. They also depart from each other in terms of public image. Although both are stigmatised as materialistic and allegedly prone to domestic abuse, they and their transnational ties are perceived differently. In popular discourse, from being seen as impoverished and rural (Hsia 2007), Vietnamese women are now more viewed as having links with a land of economic opportunities which benefit Taiwanese overseas investment (e.g. Global Vision 2016), whereas Chinese women continue to be associated with an antagonistic and bullying China (see below).

Secondly, excluding smaller political parties, we concentrate on the two mainstream parties because they are more likely to win elections and form a government. However, we acknowledge that smaller parties, such as the New Party, Taiwan Solidarity Union or the Chinese Unification Promotion Party, also intend to attract immigrant votes or promote their distinctive migration agenda.

Thirdly, we have included Chinese immigrants' interaction with the PRC government in our case study, since we argue that this relationship was part and parcel of their political participation. We did not investigate the relationship between Vietnamese immigrants and the Vietnamese government, largely owing to the obviously different nature of Taiwan's relationships with Vietnam and China. Although adopting a One China Policy, Vietnam raises no objection towards their citizens' renunciation of Vietnamese citizenship in order to acquire Taiwanese citizenship (Cheng 2017). Although in dispute with Taiwan concerning the sovereignty of the Spratly Islands in the South China Sea (Chemillier-Gendreau and 
Sutcliffe 2000), Vietnam does not pose a threat to Taiwan's survival. In contrast, denying Taiwan's sovereign claim to the territory under its jurisdiction, the PRC, particularly in its posture as a global power, insists on regarding Taiwan as a renegade province to be reunited with the mainland, by force if necessary.

Illustrated by the experiences of Vietnamese and Chinese migrant spouses in Taiwan as justified above, this research argues that transnational ties are politicised by the mainstream political parties in Taiwan. However, such politicisation does not necessarily restrict immigrants' agency or their socio-political space for political participation. Their socio-economic links and cultural heritage spanning state borders constitutes a dynamic socio-political field that is intersected by popular discourses and public policies. Whether as asset or liability, these connections are subjectively interpreted by immigrants and give rise to a variety of strategies for addressing issues affecting their wellbeing.

Pursuant to this research design, we examine the following two questions: How do political parties of the receiving state incorporate immigrants' transnational ties into their campaign strategies? How do immigrants react to political parties' electioneering in their political participation? Our investigation utilises campaign materials from the presidential election of 2016 and interviews with a number of Vietnamese and Chinese activists (respectively, in April and December 2017 in southern Taiwan, and between 2014 and 2016 in Taiwan and China). ${ }^{1}$ Instead of conducting a large- $\mathrm{N}$ comparison between the two groups, we used activists as proxy because of their rich experiences that illustrate how transnational ties may be resources for political participation. Going further than their Vietnamese counterparts, the Chinese activists established political parties to promote their political beliefs. Instead of conceiving them as exceptional, this research regarded their act as arising from the unfriendly socio-political environment and highlighting their confidence in reclaiming the ownership of their transnational ties and transforming the perceived liability into a source of empowerment.

\section{APPEALING TO A FEMINISED CONSTITUENCY}

As of June 2017, the number of immigrant men and women who resided in Taiwan on the basis of being local citizens' spouses amounted to 523,859, with the overwhelming majority of them being female (92.03 per cent) (NIA 2017). A total of 173,973 of these non-local spouses are from Southeast Asia (Vietnam, Indonesia, the Philippines, Thailand, Cambodia and a few other countries). Another group of 334,583 spouses are from the PRC, excluding those from Hong Kong and Macao. Amongst these male and female spouses, 243,017 of them have acquired citizenship, including 119,234 foreign nationals and 123,783 from the mainland PRC (NIA 2017). Before the general election that took place in January 2016, these foreign-born citizens comprised 1.33 per cent of the entire electorate (CEC n.d.). The underrepresentation of Chinese spouses amongst foreign-born citizens derives from the differentiated citizenship legislation, whereby foreign and Chinese immigrants are required to meet different criteria. One of the most significant differentiations is the

\footnotetext{
${ }^{1}$ For analytical delineation and to protect interviewees' identity, all interviewees are referred to by pseudonyms.
} 
duration of residency in Taiwan required for citizenship eligibility: for foreign spouses, it is no less than four years; for Chinese, it is a minimum of six years. ${ }^{2}$ Closing this gap has been a consistent campaign goal for the Alliance for Human Rights Legislation for Immigrants and Migrants (AHRLIM) (Hsia 2009; Liao 2009), a coalition of advocacy organisations whose group members include the Marriage Association of the Two Sides of China (MATSC), an organisation leading the Chinese immigrants' rights-claim movement (Momesso and Cheng 2017).

Given AHRLIM's leadership in negotiating with incumbent governments since the 2000s for reform of immigration legislation and maintaining communication with both parties (interview with an AHRLIM activist, 26 April 2017, Taipei), its examination of the two parties' policy manifestos is worth noting. AHRLIM considered the following four issues as priorities for legislative amendment: reforming the discriminatory spousal visa interview (applying to foreign nationals of 21 medium- and low-income states), equalising the qualifying duration of residency for citizenship eligibility for Chinese and foreign spouses, dropping "good character" as a prerequisite for citizenship eligibility, and reducing the instances of statelessness consequent on immigrants' renouncing their native nationality to be eligible for citizenship. Answering AHRLIM's inquiry, the KMT confirmed that it supported the continuation of spousal visa interviews, endorsed equalisation, consented to cancel the "good character" precondition, and agreed to grant nationality prior to renunciation. In contrast, the DPP also insisted on maintaining spousal visa interviews, disagreed with equalisation because of security concerns towards the Chinese, supported retaining the "good character" requirement but would refine the regulations, and avoided answering the question about renunciation (TASAT 2016). Therefore, on AHRLIM's balance sheet, the two parties could claim credit for being "immigrant-friendly" only to a limited degree. Underneath their proclaimed commitment to improving immigrants' wellbeing, the DPP appeared more prepared to fence off Taiwan as a "walled state" (Brown 2010), particularly towards Chinese immigrants.

The characterisation of immigrants' transnational ties has been part of the two parties' electioneering. Seeing that no additional votes could be gained by "dividing" the electorate along their ethnicity, the KMT conceptualised immigration issues as meeting the needs of disadvantaged women, including local, foreign and Chinese. Emphasising the necessity of being ethnicity-conscious towards the whole electorate, local and immigrant alike, the DPP underlined the necessity of catering to immigrants' needs arising from their different cultures, such as promoting immigrants' languages (Cheng and Fell 2014). Although the foundation of differentiated citizenship legislation affecting Chinese and foreign immigrants was laid by the KMT during the 1990s when major immigration legislation was promulgated (Cheng 2016b), after 2000 the two parties diverged from each other in their track record of law-making (Tseng et al. 2014). The DPP's amendments to the legislation, the most criticised of which were setting a high financial threshold for citizenship eligibility for both groups and a failed attempt to further elongate the residency requirement for Chinese immigrants, overshadowed the party's pledge to protect human rights (Liao 2009;

2 Article 17, the Act Governing Relation between the People of Taiwan Area and the Mainland Area (henceforth the Cross-Strait Act). 
Hsia 2009). By moderating such regulations, and particularly granting the right to work to the Chinese, the KMT earned itself an immigrant-friendly reputation. This partly explained why Chinese immigrants do not feature in the KMT's publicity campaign, since it is not cost-effective to pour resources into winning an already secured constituency (Cheng 2018). However, it can also be argued that the absence of the Chinese, which is also the case for the DPP's publicity, is to avoid making itself vulnerable over the political sensitivity surrounding Chinese immigrants, who in popular discourse are speculated to be serving the PRC's interests in interfering in Taiwan's politics. That is, the acquisition and exercise of citizenship of Chinese immigrants is perceived as a potential source of instability to the Taiwanese identity and to political parties' vote share because of their indoctrination in socialism and Chinese nationalism (Friedman 2015; Cheng 2016a).

Evolving from these time-tested campaign strategies, the two parties adopted different strategies in their public communication for appealing to this feminised constituency in the 2016 general election. The KMT was particularly noted for its creation of representation in the legislature for migrant spouses. The party made Lin Li-chan, a long-term volunteer and self-trained activist from Cambodia, a legislator without constituency (bufenqu, 不分區). Featured in a TV ad released on 19 December 2015, Lin called on her fellow immigrants to "truly make themselves Taiwanese" (emphasis added). Lin's ad ended with the appeal "bufenqu means it doesn't matter where you come from". Arguably, not only did it refer to migrant spouses' multiple origins but also promoted Lin as an encompassing delegate for all migrants from the PRC, Southeast Asia and beyond. By creating a central figure for embodying this institutional representation, the KMT seemed to suggest that plurality and diversity are the symbolic values derived from immigrants' transnational ties, including those of the Chinese. On the whole, adaptation ("truly Taiwanese") was placed together with plurality and diversity in Lin's message.

Rather than creating a focal figure like Lin Li-chan, the DPP showcased its embrace of the transnational ties of Southeast Asian immigrants, and sidelined Chinese immigrants, at festive rallies and via its public policy. On 21 October and 5 December 2015, two supporters' groups joined by Southeast Asian spouses only were established, and the DDP Chairwoman Tsai Ing-wen received their endorsement for her presidential candidacy (Tsai Ing-wen Facebook, 21 October and 6 December 2015). The non-participation of Chinese immigrants was a deliberate strategy, according to Cao Nhập Phải, a DPP member of staff involved in the mobilisation of immigrant voters (see below). On 3 July 2015, the electorate saw on TV the scholarly Chairwoman dress like the Vietnamese tea-pickers she stood alongside and listening to the latter's stories of adaptation spoken intermittently in Mandarin and Taiwanese. Treated as the guest of honour at a feast of Vietnamese cuisine cooked by the women, Tsai concluded, "This is the Taiwan close to my heart. Whenever you came here, we can always find ways to embrace each other" (The Storm Media 2015, emphasis added). The DPP's appeal to Southeast Asian immigrants' transnational heritage was also packaged into its foreign policy. Eyeing up the rapid growth of Taiwan's trade partners in Southeast Asia, the DPP proposed to enhance Taiwan's economic relationships with Southeast Asian states (Light Up Taiwan 2015), an initiative later officially branded as the New Southbound Policy, the publicity of which projects 
Southeast Asian immigrants and their children as the bridge between Taiwan and their countries of origin (Office of the President 2016).

As far as the characterisation of transnational ties goes, the above examination suggests that both parties blended assimilation with multiculturalism without making reference to the Chinese. In spite of Lin Li-chan's call for being "truly Taiwanese", her nomination was the KMT's gesture towards recognising diversity and encouraging inclusiveness, arguably including the Chinese. Although Southeast Asian immigrants' transnational ties were recognised by the DPP's New Southbound Policy, the fact that the Vietnamese tea pickers in the TV ad narrated their experiences of becoming Taiwanese in fluent local languages indicated the DPP's endorsement of assimilation. In sum, the two parties were at ease with Southeast Asian immigrants' transnational bonds. What set the two parties apart, as underlined by their divergence over the issue of equalisation, was how they responded to Chinese immigrants and their link to China.

In the light of these findings, the following sections will analyse how the Vietnamese and Chinese activists interacted with electoral politics in Taiwan, and specifically, how the Chinese interacted with the PRC government's outreach programme.

\section{VIETNAMESE ACTIVISTS: UTILISING ADVANTAGEOUS TRANSNATIONAL LINKS}

As explained above, this research used the subjective understanding of Vietnamese activists as a proxy to investigate how immigrants interact politically with the mainstream parties through their transnational ties. The activists interviewed are Ngô Xuân Phuong, the head of a self-help organisation in Touliu, who also includes interpreting, air ticketing, and custom-made áo dài tailoring in her business portfolio; Trinh Minh Ha, a full-time employee at a grassroots organisation in Pingtung; Hồ Minh Mai, an experienced Vietnamese language teacher and a frequent speaker at immigrants' orientation seminars organised by the local government in Tainan; Ly Van Trang, a documentary maker and the founder of a self-funded immigrant community centre in Chiayi; and Cao Nhập Phải, a DPP member of staff during the election who was recruited for mobilising Southeast Asian voters.

As migrant spouses, their trajectory of participation in public affairs was a rite of passage punctuated by gender. Developing from the private home where they provided care for family members with or without waged employment outside of the home, they built up their social networks beyond family via employment, entrepreneurship or education. As their Chinese proficiency grew or was formally certified for providing interpreting services, they began to volunteer at social organisations or local government agencies, or were invited to speak at public seminars aimed at smoothing immigrants' orientation. Becoming opinion leaders respected by their fellow immigrants and connected with activists of varying nationalities in other counties, they were either approached by political parties to play leading roles in the supporters' organisations or they themselves had contemplated the possibility of running for public office. The career of Lin Li-chan has set a precedent for their aspiration.

If acquiring socio-cultural capital is a necessary condition for political 
participation, so too is a strong motivation. Motivated by a concept of "care" expanded from being a home-based, gendered private duty for family members to a commitment to public engagement for helping other "immigrant sisters", Trinh Minh Ha stressed the sense of mission to fight against the gender-biased discrimination:

Now that we've got to know better about Taiwanese society, there are things [about which] we'd like to make our voices heard. We know we've been denounced as women who came here for "stealing money"; a negative image was imposed on us. What can we do about it? In the past, the government wasn't interested in dealing with such issues. We were told the priority was to adapt to the way of life of Taiwan. But now I think the [DPP] government is more responsive; I think our efforts have been recognised. (Interview, 11 December 2017, Pingtung; emphasis added)

The brighter prospect seen by Minh Ha may be largely due to the generous funding rendered by the DPP's wholesale promotion of its New Southbound Policy. At events funded by the government, under the aegis of multiculturalism or community building, Southeast Asian immigrants' transnational ties are upheld as being to Taiwan's economic and cultural advantage by deepening the relationships with their countries of origin. When civil servants in local governments had no clear clues as to how to design multicultural events to meet the requirements sent down from the central government, these experienced activists came to their aid. Although Ngô Xuân Phuong suspected that funding was abused by some to "fatten themselves up" (interview, 13 April 2017, Touliu), other activists welcomed its contribution to the introduction of Southeast Asian languages and cultures, the enhancement of public awareness of immigrants' human rights, and the stress on immigrant women's empowerment. Nevertheless, Ly Van Trang's dedication to protecting migrant workers' human rights also prompted her to make the criticism that migrant workers were neglected by political parties because they could not vote thus do not exist in electoral politics (interview, 17 April 2017, Chiayi). However, the celebration of Southeast Asian immigrants' heritage did not seem to lead to changes in actual party policies. As discussed above, on AHRLIM's policy checklist, neither the KMT nor the DPP looked convincingly immigrant-friendly. When asked about the AHRLIM's findings, Cao Nhập Phải explained that he had come to terms with the reality that policy inputs from the grassroots level could be "filtered, diluted and finally diminished" in their journey from the bottom to the top through the party's decisionmaking hierarchy (interview, 12 December 2017, Tainan).

On the organisational front, to reach out to Chinese and Southeast Asian immigrant voters, the KMT had established local offices within its Women's Department since the 2012 election (interviews: a late KMT councillor, 18 July 2013, Taipei; a Taiwanese activist, 11 December 2017, Pingtung). Whilst the KMT's initiative requires further empirical examination into its effectiveness, the DPP's cultivation of its relationship with Southeast Asian activists seemed to have paid off. Surveying Southeast Asian activists' potential influence over their fellow immigrants, Nhập Phải sought the recommendations of such opinion leaders in each county and then recruited them to join the DPP's fan groups. His mission could not have been 
completed had there not already been established networks amongst these activists. After all, he himself was recruited via such personal recommendation (interview, Hồ Minh Mai, 11 December 2017, Tainan). The DPP's outreach message and appeal to inclusion was personally delivered by Tsai Ing-wen's tea-picking TV ad. Nhập Phải confirmed that this ad was at the initiative of the party's local branch. In a remote village in central Taiwan, the Vietnamese tea pickers, who were geographically and socio-economically distant from the presidential candidate, warmly welcomed Tsai because her presence was interpreted as paying respect towards them.

"Respect" was the concept stressed time and again by interviewees in our fieldwork. An immigrant voter may cast her vote for a politician who has helped in solving her problem; she may also support this politician if he/she shows respect by visiting her at home, shop, public events, or presenting a certificate acknowledging her membership in the supporters' group. Photos taken with a politician are often accorded a great social value that derives from the sense of being respected. In this regard, an activist may play an intermediary role between politicians and their target voters. Whether bi-partisan or supporting a specific party, interviewed activists confirmed that because of mutual trust, they could influence other immigrants' voting preferences by recommending a candidate or passing information about a rally event, whilst encouraging their fellow immigrants to be "open-minded". However, such external influences would be weighed against family preferences, particularly if the recommendation conflicts with their in-laws' preference, or disturbs the distribution of votes dictated by their parents-in-law whose voting decision is agreed on with election agents (interviews: Lin Li-chan, 8 December 2017, Taipei; Trinh Minh Ha, 11 December 2017, Pingtung). It is noteworthy that mothers-in-law were often identified as the person who expressly dictated their foreign daughters-in-law's voting decision. Nhập Phải was open about being influenced by his in-laws, who were staunch DPP supporters. Minh Mai was adamant that although influenced by her husband's support for the DPP, she was bi-partisan and did not hold out any expectations towards either party. As a matter of fact, the employer of the Vietnamese tea pickers was also a DPP hardliner, whose support facilitated Tsai Ing-wen's short-lived tea-picking career. These incidents illuminated the impact of family influence and social networking on immigrants' political inclinations.

The above analyses show that the DPP's outreach to the Southeast Asian constituency met an active response from the interviewed Vietnamese activists. The party's politicisation of their transnational bonds was broadly perceived as a sign of respect, as a boost to their empowerment, or as a source of practical contribution to their activism. Vietnamese activists participated in the party's vote mobilisation and image construction, whilst the party seemed to fall short of reciprocating their support in policy-making. On the whole, immigrants' transnational bonds appeared to be resources for their political participation.

\section{CHINESE ACTIVISTS: TRANSFORMING THE VALUE OF TRANSNATIONAL LINKS}

As analysed above, identity and entitlement constitutes the axis of Chinese immigrants' political socialisation in Taiwan. Inseparable from their transnational ties with mainland China, they are confronted with the divide between Chinese identity 
and Taiwanese identity, which is complicated by the two parties' policies towards China. Their transnational ties also explain their unfavorable legal status: in addition to unequal citizenship eligibility, they cannot be candidates for public offices, serve in the government, education institutions or state enterprise, or organise political parties until ten years after they have acquired citizenship. ${ }^{3}$ Under such circumstances, stronger identification is built between them and the KMT, which appears friendlier than the DPP due to the party's overall Chinese identity, and, in particular, its less confrontational policy towards China and more accommodating immigration legislation between 2008 and 2016. A census conducted by the government in 2003 found that 10 per cent of Chinese-Taiwanese couples relied on a pension as the main source of family income (MoI 2004), which indicated that the Taiwanese husbands were most likely Mainlander veterans. For some, affinity with the KMT coincided with their Mainlander husbands' long-term KMT membership. Liu Yixiang from Shanghai was one of our interviewees whose husband is a long-standing KMT member and who joined the KMT after having acquired citizenship (interview, 25 February 2011, Taipei). Speaking of her impressions, Zhou Hui, a native Sichuanese, suggested that "The majority of Mainland spouses are married to KMT members, civil servants, and elderly Mainlander veterans. These people have deep connections with the KMT" (interview via Skype, 16 September 2016). To appeal to these potential supporters, not only the KMT's Women's Department and local branches but also its Veteran Department (interview, a KMT legislator, 10 July 2013, Taipei) reached out to Chinese spouses for its organisational mobilisation and recruited them to join election rallies. However, demography was not static; as noted by Zhou Hui, the number of marriages with elderly Mainlander veterans had declined (interview via Skype, 16 September 2016). Therefore, the evolving demography of Chinese immigrants would not generate sustainable electoral dividends for the KMT.

Given this changing demography, the KMT could secure Chinese immigrants' support by meeting their demand to shorten the required residency for citizenship eligibility to four years, as pointed out by a KMT legislator (interview, 8 December 2017, Taipei). The KMT government tabled such an amendment to the Legislative Yuan in November 2012 (EY 2012). However, the amendment could not be assigned to the Committee of the Home Affairs for consideration due to the persistent objections of the DPP and the Taiwan Solidarity Union (LY 2012a). This deadlock was not solved until the KMT won an open vote in December that enabled the amendment to be reviewed (LY 2012b). ${ }^{4}$ Blaming the DPP's previous obstruction (interview, a former minister overseeing this issue, 16 March 2015, London), the KMT failed to push through this crucial reform before handing power to the DPP in May 2016. It is not surprising that there was a sense of betrayal towards the KMT amongst Chinese immigrants, as an interviewee from Wuhan argued, "I think the DPP did not care about us. But I think the KMT didn't really consider us, either!” (interview, 1 July 2012, Taipei). Zhang Yuru, a native Fujianese migrating to Taiwan in 1992 and acquiring citizenship in 2001, was a KMT volunteer who claimed

\footnotetext{
${ }^{3}$ Article 21, the Cross-Strait Act.

4 After the general election of 2012, the amendment was re-submitted in February 2016 (EY 2016).
} 
to have become an experienced election agent for voter mobilisation. She was critical of the KMT's record in meeting their interests:

I had worked in the KMT for eight years as a volunteer. Almost each year there was some kind of election in Taiwan. [...] So the KMT asked us to help them with their campaign, but when we approached them for our needs, they did not consider us. [...] We spent time, energy and money in going to their meetings. What is that for? It is only for them to mobilise our votes. (Interview, 23 May 2016, Xiamen)

For those who actively supported the KMT, confusion also arose from the nomination of Lin Li-chan rather than a Chinese candidate given the latter's obvious majority. This was raised by Lin Meiyu (from Jiangxi), who founded a grassroots organisation in Taichung (interview, 6 November 2016, Taichung). Such frustrations led some Chinese activists to take matters into their own hands and establish new political parties (Momesso 2017). These are the Chinese Production Party (founded in 2010, henceforth the Production Party), the Chinese New Residents Party (established in 2012, henceforth the Residents Party), and the New Residents' Republican Party (founded in 2014 as a splinter from the second party, henceforth the Republican Party). They were amongst a total of 305 political parties registered with the Ministry of the Interior as of 2016 (MoI 2017). Excluded by the DPP and distrusting the KMT, these Chinese activists sought self-representation as an alternative. As Yang Yaping, a key figure of the Residents Party, explained:

Since the KMT is in power, our interests can be represented at the Legislative Yuan. But we want our own party now. In the past, because we were not entitled to participate in politics, we had to rely on Taiwanese political parties. But now it is different, many spouses have been in Taiwan for two decades or more and they have gained the right to join and establish political parties. (Interviewed, 3 October 2014, Taipei; emphasis added)

Yang's aspiration for self-representation was echoed by Zhang Yuru, who later became an influential member of the Production Party. Zhang explained that "If we elect a legislator to the Legislative Yuan, it will give us power to affect politics" (interview, 23 May 2016, Xiamen, emphasis added). Their vision of achieving political efficacy through standing for election was shared by the Republican Party, as confirmed by Liang Zhijun, a significant figure in the party (interview, 3 October 2014, Taipei).

Self-representation has also enabled them to express their Chinese identity and speak out about their preference for peace between Taiwan and China, both of which characterise their transnational ties growing after migration. There is no denying that Chinese immigrants boast of Chinese identity, whereby the relationship between Taiwan and China is understood as a hierarchy: Taiwan, in the periphery, along with its Han Chinese people, is a cultural derivation from the core of continental China. However, migration to Taiwan has confronted them with an array of cognitive challenges that destabilise this conceptual hierarchy. Some of these challenges are as 
significant as the administrative measures regulating their movement across the Taiwan Strait (the border between Taiwan and China); some others are as mundane as their daily encounters with husbands, step-children, in-laws, colleagues, employers and strangers. These cognitive challenges have brought them to acknowledge the existence of Taiwanese identity (Cheng 2016a); some of them attributed the rigidity of their conceptual hierarchy to the PRC's indoctrination. Whilst they continue to uphold their Chinese identity, their transnational life style has also made them live 'here and there' (Zani 2018). Some of them, particularly those who became mothers, adopted certain aspects of the way of life in Taiwan, such as linguistic habits and mannerisms, which contribute to the growth of their local identity side by side with their Chinese identity.

It is within this gradual and incremental adjustment of identification that both the Residents Party and the Republican Party incorporate their support for the peaceful unification of Taiwan and China in their mission statement. The Residents Party Charter calls for the "rejuvenation of the Chinese nation" (fuxing zhonghua minz, 復 興中華民族). This is nearly identical to the PRC's slogan of the “great rejuvenation of the Chinese nation” (zhonghua minzu weida fuxing, 中華民族偉大復興,) and the unity of the Chinese nation (Mahoney 2014; Wang 2014; Bislev 2015). The fact that the Residents Party was co-founded by Taiwanese citizens was stressed by Yang Yaping as an indication that the eventual unification was also envisaged by some people in Taiwan (interview, 3 October 2014, Taipei). Thus, in the eyes of these Chinese activists, support for unification was where congruence could be found between them and some Taiwanese citizens. On the other hand, this agenda runs the risk of distancing Chinese immigrants from their Southeast Asian counterparts. As Liang Zhijun noted, those foreign spouses who visited their party office would never return, because "for them peaceful unification is not really an issue!" (interview, 20 October 2014, Taipei).

Their expressed support for unification significantly departed from the earlier self-restraint shown in a non-political and bi-partisan stance that was consciously adopted by the Chinese migrants' movement during the DPP presidency (Chang 2004; Cheng 2016a). Their confidence in promoting unification might have been encouraged by the rapprochement between Taiwan and China during the KMT presidency, given that these parties were founded during that period. Arguably, it might also be a response to the PRC government's attempt at outreach. Since the first half of the 2000s, the Chinese government has established regular exchanges with Chinese immigrants' organisations in an unofficial, closed-door and low-profile manner. However, in 2012, during the KMT presidency, the founding of the CrossStrait Marriage and Family Service Centre and the Cross-Strait Marriage and Family Association (Wei 2014) may have signalled a change to a more institutionalised but family-oriented approach. As stressed by Wang Yi, the former head of Taiwan Affairs Office, "marriage has nothing to do with politics" (CSMFA 2014: 63, emphasis added), a phrase often heard in our interviews with Chinese immigrants in the context of equalising citizenship eligibility. Overseen by the PRC's Ministry of Civil Affairs, the two organisations have hosted the annual meeting of the Cross-Strait Marriage and Family Forum, organised summer camps in China for children of transnational families, and invited Chinese spouses (including Zhang Yuru and Yang Yaping, 
interviewed for this research) for home visits (CSMFA 2014: 6-13, 30, 36-39; Wei 2014).

The Chinese government's approaches were positively received by Chinese activists. After all, marriage migration to Taiwan does not necessarily enjoy a positive reception in China. In Zhang Yuru's words, "For sure the mainland government cares about us now. There are 400,000 of us, and you should also add our family members. We are a form of power" (interview, 23 May 2016, Xiamen). Above all, they interpreted Beijing's new interest in them not only as facilitating a transnational channel in which their public profile can be raised and their socio-economic pursuits can be realised, but also as recognising their potential as an emerging political force in Taiwan and their contribution to maintaining peace between the two societies.

In the wake of social movements where anti-China sentiments featured significantly in the public discourses (Rawnsley 2014; Rowen 2015), these Chinese activists' political vision would naturally raise many eyebrows. A prominent DPP member cautioned against the scenario in which Chinese immigrants served the PRC's interest in 'sway[ing] the presidential election' and 'decid[ing] Taiwan's future' (Taipei Times 2014). Nevertheless, it is necessary to put their aspirations in context. Their parties are in the process of developing an appealing agenda, affirming their identity, searching for funding, and identifying their potential supporters. Small parties campaigning on a single issue rarely fare well in general elections, especially those using 'first-past-the-post' single member district electoral systems (Fell 2016). Their votes would be more effective in local elections (Cheng 2018), where the semiproportional single non-transferable vote system is adopted. It is also questionable whether the parties established by Chinese immigrants are receiving support from their prospective constituency. Our fieldwork findings suggest that, amongst Chinese immigrants, their parties were neither widely known nor did they communicate effectively with those who were aware of their existence. Thus, their resort to selfrepresentation could be understood as a bid to overcome the unfavourable sociopolitical constraints on their political participation and to express their frustrations at the faltering reform of their unequal citizenship eligibility. Their political participation and the eligibility reform have unfortunately fallen prey to partisan politics and the fluctuating relationship between Taiwan and China. Although the KMT failed to meet their expectation of closing the citizenship eligibility gap, its overall posture and the moderated relationship with China opened new political opportunities for them to speak out for what they saw as integral to their transnational ties.

\section{CONCLUSION}

Built on the rubric of transnationalism, this research is a preliminary attempt at exploring whether and how the "politics of in-between" (Jones-Correa 1998a) resonates with the political participation of immigrant voters in Taiwan. The originality of our research lies in our recognition of the dynamics of the "politics of in-between" in the activism of Vietnamese and Chinese immigrants in their responses to electioneering and partisan politics in Taiwan.

Our findings caution that the two parties' electioneering did not seem to have a real impact on their immigration policies. As shown by AHRLIM's examination of their policy manifestos, the two parties fell short of responding to the persistent calls 
to reform spousal visa interviews, equalise the residency duration required for Chinese immigrants' citizenship eligibility, abolish the "good character" requirement for naturalisation, and reduce potential statelessness as a result of renunciation. It remains to be answered as to why the KMT failed to reform citizenship eligibility, arguably at the expense of losing votes. Similarly, it also requires further empirical and analytical insights into how policy recommendations from the grassroots level might be "lost" in the DPP's decision-making. Underlining this startling disparity between image, promise and reality is one of this paper's major contributions to the debate concerning the impact of civil society on policy-making and policy output.

As for immigrants' responses, our research shows that immigrant activists could utilise the politicisation of their transnational ties in advancing their agenda or promoting their transnational identity, as argued by the analytical concept of the "politics of in-between". The Vietnamese benefited from the DPP's endorsement of their transnational links, whereas the Chinese endeavoured to redress the exclusion of their transnational bonds in Taiwan, which partly resulted in their welcoming the PRC government's outreach efforts. The Vietnamese activists we interviewed made use of these newly opened political opportunities to advocate their causes or contribute to the DPP's image construction. In contrast, being excluded from the socio-political sphere, Chinese immigrants continued to negotiate a critical public reception with their newly acquired confidence in speaking out about their transnational identity. Gender is also at play in the two group's political experiences. Gender underlines Vietnamese interviewees' activism in their transition from being home-based private carers to activists who expand their care to include their fellow immigrants. Gender also punctuates the Chinese government's conceptualisation of the immigrants' transnational ties as family bonds.

Beyond the local Taiwanese context, our research suggests that "the politics of in-between" is a useful analytical approach to understanding immigrants' fluid identities and their strategies of utilising political opportunities available in electoral politics. It encourages us to explore how specific immigration policies pursued by the host or origin state may facilitate a socio-political space in which immigrants can take advantage of their in-betweenness and promote their own interests in a public forum. Our research also calls for further investigation into whether and how incentives may be generated for mainstream partisan politics of the host state to engage with immigrants' advocacy organisations for policy-making.

\section{REFERENCES}

Barreto, M. A.

2005 "Latino immigrants at the polls: foreign-born voter turnout in the 2002 election", Political Research Quarterly, 58(1): 79-86.

Barreto, M. A. and Muñoz, J. A.

2003 "Reexamining the 'politics of in-between': political participation among Mexican immigrants in the United States", Hispanic Journal of Behavioral Sciences, 25(4): 427-447. 
Barreto, M. A., Manzano, S., Ramirez, R. and Rim, K.

2009 "Mobilization, participation, and solidaridad: Latino participation in the 2006 immigration protest rallies", Urban Affairs Review, 44(5): 736-764.

Beckershoff, A.

2014. "The KMT-CCP forum: securing consent for cross-Strait rapprochement", Journal of Current Chinese Affairs, 43(1): 213-241.

Bislev, A.

2015 "The Chinese dream: imagining China", Fudan Journal of Humanities and Social Science, 8: 585-595.

Briones, L.

2009 Empowering Migrant Women: Why Agency and Rights Are Not Enough,

Aldershot: Ashgate.

Brown, W.

2010 Walled States, Waning Sovereignty, Cambridge, MA: MIT Press.

Castles, S.

2000 Ethnicity and Globalization: From Migrant Worker to Transnational Citizen, London: Sage.

Castles, S. and Miller, M. J.

2009. The Age of Migration: International Population Movements in the Modern World, 4th Edition, London: Palgrave Macmillan.

CEC (Central Election Commission)

n.d. “The election of the 14th President and Vice President”(第14任總統(副總統)選 舉) (in Chinese), at http://db.cec.gov.tw/histQuery.jsp?

voteCode=20160101P1A1\&qryType=prof (retrieved 11 March 2018).

Chang, H-C.

2004 Online Practices of the Struggle for Citizenship of Cross-Strait Couples: A Case Study of the Forums of Cross-Strait Park and Cross-Strait Family (兩岸婚姻者 爭取大陸籍配偶公民權的網路實踐一以 [兩岸公園],[兩岸家庭] 論壇為例). Master's Degree Dissertation, Chiayi: Chung Cheng University.

Chemillier-Gendreau, M. and Sutcliffe, H. L.

2000 Sovereignty over the Paracel and Spratly Islands, The Hague: Kluwer Law International.

Cheng, I.

2016a "Bridging across or sandwiched between? Political re-Socialisation of Chinese immigrant women in Taiwan", Asian Ethnicity, 17(3): 414-434. 
$2016 \mathrm{~b}$ "Cross-Strait marriages and immigration policies", in Schubert, G. (ed.) Routledge Handbook of Contemporary Taiwan, 446-462, Abingdon: Routledge.

2017 "She cares because she is a mother: the intersection of citizenship and motherhood of Southeast Asian immigrant women in Taiwan", in Fresnoza-Flot, A. and Ricordeau, G. (eds.) International Marriages and Marital Citizenship: Southeast Asian Women on the Move, 158-175, Abingdon: Routledge.

2018 "Are they worthy of it? Desirability and accountability in the governance of migration under the Ma administration", in Schubert, G. (ed.) Hopeful Beginning, Hopeless End? Assessing the Mai Ying-jeou Era in Taiwan (20082016), 32-158, Abingdon: Routledge.

Cheng, I. and Fell, D.

2014 "The change of ruling parties and Taiwan's claim to multiculturalism before and after 2008", Journal of Current Chinese Affairs, 43(3): 71-103.

Cho, W. K. T.

1999 "Naturalization, socialization, participation: Immigrants and (non-)voting", The Journal of Politics, 61(4): 1140-1155.

CSMFA (The Cross-Strait Marriage and Family Association)

2014 Serving Cross-Strait Marriages and Families (兩岸婚姻家庭服務) (in Chinese), Beijing: CSMFA.

Elshtain, J. B.

1974 "Moral woman and immoral man: A consideration of the public-private split and its political ramifications", Politics \& Society, 4: 453-473.

EY (The Executive Yuan)

2012. The Draft Bill of the Amendment of Article 17 of the Act Governing Relation between the People of Taiwan Area and the Mainland Area Submitted to the Legislative Yuan .The Legislative Yuan General No. 1554, The Initiative of Government No. 13439 (立法院議案關係文書院總第1554號,政府提案第 13439號,案由：行政院函請審議「臺灣地區與大陸地區人民關係條例第十 七條條文修正草案」案), 21 November.

2016 The Draft Bill of the Amendment of Article 17 of the Act Governing Relations between the People of Taiwan Area and the Mainland Area Submitted to the Legislative Yuan .The Legislative Yuan General No. 1554, The Initiative of Government No. 15560 (立法院議案關係文書院總第1554號,政府提案第 15560 號, 案由：行政院函請審議「臺灣地區與大陸地區人民關係條例第十 七條條文修正草案」案), 17 February.

Fell, D.

2016 "Small parties in Taiwan's 2016 national elections: A limited breakthrough?", American Journal of Chinese Studies, 23(1): 41-58. 
Fennema, M. and Tillie, J.

2001 "Civic community, political participation and political trust of ethnic groups", Connections, 24(1): 26-41.

Friedman, S.

2015 Exceptional States: Chinese Immigrants and Taiwanese Sovereignty, Stanford: University of California Press.

Gidengil, E., O’Neill, B. and Young, L.

2010 "Her Mother's daughter? The influence of childhood socialization on women's political engagement", Journal of Women, Politics \& Policy, 31(4): 334-355.

Glick Schiller, N. et al.

1995 "From immigrant to transmigrant: theorizing transnational migration", Anthropological Quarterly, 68 (1): 48-63.

\section{Global Vision (遠見雜誌)}

2016. “Why would Taiwan increase investment in Vietnam against all odds?” (台灣為 什麼逆勢加碼越南？) (in Chinese), 27 October, at https://www.gvm.com.tw/ article.html?id=22288 (retrieved 18 June 2018).

Grillo, R. and Salih, R.

2000 Here or There? Contrasting Experiences of Transnationalism: Moroccans and Senegalese in Italy, Falmer: University of Sussex.

Hammar, T.

1990 Democracy and the Nation State: Aliens, Denizens and Citizens in a World of International Migration, Aldershot: Avebury.

Harell, A.

2009 "Equal participation but separate paths? Women's social capital and turnout", Journal of Women, Politics and Polity, 30(1): 1-22.

Ho, C.

2008 “Diversifying feminism: migrant women's activism in Australia", Signs 33(4): 777-784.

Hsia, H-C.

2007 "Imaged and imagined threat to the nation: the media construction of the 'foreign brides phenomenon' as social problems in Taiwan”, Inter-Asia Cultural Studies, 8(1): 55-85.

2009 "Intellectual intervention and the making of im/migrant movement I" (知識介入 與移民／工運動的推進（一）) (in Chinese), Taiwan: A Radical Quarterly in Social Studies, 74: 367-382. 
Hsu, S. P.

2010. "Between identity quest and risk aversion: Lessons from the Chen Shui-bian presidency for maintaining cross-Strait stability", Journal of Contemporary China, 19(66): 693-717.

Jacobs, D., Martiniello, M., \& Rea, A.

2002 "Changing patterns of political participation of citizens of immigrant origin in the Brussels Capital Region: the October 2000 elections", Journal of International Migration and Integration, 3(2): 201-221.

Jones-Correa, M.

1998a Between Two Nations: The Political Predicament of Latinos in New York City, Ithaca: Cornell University Press.

1998b "Different paths: gender, immigration and political participation", International Migration Review, 32(2): 326-349.

Leighley, J. E. and Vedlitz, A.

1999 "Race, ethnicity, and political participation: Competing models and contrasting explanations", The Journal of Politics, 61(4): 1092-1114.

Liao, B. Y-H.

2009 “Intellectual intervention and the making of im/migrant movement II" (知識介 入與移民／工運動的推進（二）) (in Chinese), Taiwan: A Radical Quarterly in Social Studies, 74: 383-405.

Light Up Taiwan

2015 Chairwoman Tsai Ing-Wen's Address at the DDP's 29th Anniversary and Diplomats Reception, at http://iing.tw/posts/142 (retrieved 1 September 2017).

Liu, Frank C. S. and Albert S. Y. Chiu.

2011 "Network heterogeneity, partisan defection, and voter turnout: Examine theory with empirical data from Taiwan", International Journal of Business and Social Science, 2(19): 258-272.

LY (The Legislative Yuan)

2012a Floor Meeting Minutes of the Legislative Yuan Gazette, 101(81): 10 (立法院公 報第101卷第81期院會紀錄). 7 December.

2012b Floor Meeting Minutes of the Legislative Yuan Gazette, 102(2): 29-30 (立法院 公報第102卷第2期院會紀錄). 28 December.

Mahoney, J. G.

2014 "Interpreting the Chinese Dream: An exercise of political hermeneutics", Journal of Chinese Political Science, 19(1): 15-34.

Martiniello, M. 
2005 Political participation, mobilisation and representation of immigrants and their offspring in Europe, Willy Brandt Series of Working Papers in International Migration and Ethnic Relations 1/05, www.bit.mah.se/MUEP/.

Martiniello, M. and Lafleur, J. M.

2008 "Towards a transatlantic dialogue in the study of immigrant political transnationalism", Ethnic and Racial Studies, 31(4): 645-663.

MoI (Ministry of the Interior)

2004 A Census on the Living Conditions of Foreign and Mainland Spouses (外籍與大 陸配偶生活狀況調查) (in Chinese). Taipei: MoI.

2017 "The civil associations under the jurisdiction of the Central Government" (中央 政府所轄人民團體) (in Chinese), at http://sowf.moi.gov.tw/stat/year/list.htm (retrieved 31 August 2017).

Momesso, L.

2017 "Marriage migration and state interests: reflections from the experiences of marriage migrants from the People's Republic of China in Taiwan", Asiatische Studien, 70 (3): 903-920.

Momesso, L. and Cheng, I.

2017 "A team player pursuing its own dreams: rights-claim campaign of Chinese migrant spouses in the migrant movement before and after 2008", in Fell, D. (ed.), Taiwan's Social Movements under Ma Ying-jeou: From the Wild Strawberries to the Sunflowers, 219-235, Abingdon: Routledge.

NIA (The National Immigration Agency)

2017 "Numbers of foreign spouses and mainland spouses (including those from Hong Kong and Macao) by immigration status" (外籍配偶人數與大陸(含港澳)配偶 人數按證件分)" (in Chinese). At

https:/www.immigration.gov.tw/ct.asp?xItem=1333115\&ctNode=29699\&mp=1. (retrieved 11 March 2018).

Office of the President

2016 "President Tsai convenes meeting on international economic and trade strategy, adopts guidelines for New Southbound Policy", at http:// english.president.gov.tw/Default.aspx?tabid $=491 \&$ itemid $=37868 \&$ rmid $=2355$ (retrieved 10 June 2017).

Pantoja, A. D., Ricardo, R. and Segura, G. M.

2001 "Citizens by choice, voters by necessity: Patterns in political mobilization by naturalized Latinos", Political Research Quarterly, 54(4): 729-750.

Portes, A. et al. 
1999 "The study of transnationalism: pitfalls and promise of an emergent research field", Ethnic and Racial Studies, 22(2): 218-237.

Putnam, R. D.

2002 Democracies in Flux: the Evolution of Social Capital in Contemporary Society, Oxford: Oxford University Press.

Rawnsley, Ming-yeh, T.

2014 "Anti-media-monopoly policies and further democratisation in Taiwan", Journal of Current Chinese Affairs, 43(3): 105-128.

Roces, M.

2003 "Sisterhood is local: Filipino women in Mount Isa", in Piper, N. and Roces, M., (eds.) Wife or Worker: Asian Women and Migration, 73-100, Lanham, MD: Rowman \& Littlefield.

Rowen, I.

2015 "Inside Taiwan's Sunflower Movement: Twenty-four days in a student-occupied parliament, and the future of the region", The Journal of Asian Studies, 74(1): 521.

Schaffer, F. C.

2014 "Not-so-individual voting: patriarchal control and familial hedging in political elections around the world", Journal of Women, Politics \& Policy, 35(4): 349378.

Smith, M. P. and Guarnizo, L. E. (eds.)

1998 Transnationalism from Below (Comparative Urban and Community Research, Vol. 6). New Brunswick: Transaction Publishers.

Storm Media, The

2015 “To win new immigrants' support, Tsai Ing-Wen transformed to tea picker” (爭 取新移民支持, 蔡英文變身採茶姑娘) (in Chinese), at http://www.storm.mg/ article/55861 (retrieved 1 September 2017).

\section{Taipei Times}

2014 "New parties demonstrate Beijing's reach: academics", at http:// www.taipeitimes.com/News/front/archives/2014/07/23/2003595729 (retrieved 1 September 2017).

Thiara, R. K.

2003 "South Asian women and collective action in Britain", in Andall, J. (ed.) Gender and Ethnicity in Contemporary Europe, 79-95, Oxford: Berg.

TransAsia Sisters Association, Taiwan (TASAT) 
2016 “Where is immigration policy? Beef or cheque?” (移民政策在哪裡? 是牛肉還 是支票?) (in Chinese), at http://tasat.org.tw/blog/376 (retrieved 1 September 2017).

Tseng, Y.-C., Cheng, I. and Fell, D.

2014 "The politics of the mainland spouses' rights movement in Taiwan", in Chiu, K.F., Fell, D. and Lin, P. (eds.) Migration to and from Taiwan, 205-226, Abingdon: Routledge.

Wang, Z.

2014 "The Chinese dream: concept and context", Journal of Chinese Political Science, 19(1): 1-13.

Wei, J.-H.

2014 “Affection connects both sides, serve for love” (情繫兩岸, 為愛服務) (in Chinese), in Marriage Association of Two Sides of China (MATSC) (ed.), Proceedings of the Conference on the Review and Prospect of Cross-Strait Marriage in 28 Years, Chiantang Youth Activity Centre, 10 May 2014, Taipei.

Zani, B.

2018 "Trapped in migration: Migratory careers and entrepreneurial creativity of Chinese migrant women in Taiwan", China Perspective, 1/2: 75-86. 